\title{
Relationship between pest and disease incidences and agronomic operations implemented by farmers in cinnamon (Cinnamomum zeylanicum Blume) fields in southern Sri Lanka
}

\author{
G.G. Jayasinghe ${ }^{{ }^{*}}$, K.H.M.P.K. Ketakumbura ${ }^{1}$, K.G.G. Wijesinghe ${ }^{1}$, \\ K.S. Hemachandra ${ }^{2}$ and S. Weligamage ${ }^{3}$
}

\begin{abstract}
The national average productivity of cinnamon (Cinnamomum zeylanicum Blume) in Sri Lanka ( $445 \mathrm{~kg} / \mathrm{ha}$ ) is far below than the attainable yield (1000 kg/ha), which may have an association with pest and disease incidences. Pest and disease incidence was hypothesized to be correlated with awareness of farmers, agronomic practices that implemented in the field, weather parameters, and scale of farming. Hence, better understanding on these relationships is essential for planning a crop management package to increase the cinnamon yield. This study was thus, carried out to investigate the occurrence of pest and disease complex in cinnamon ecosystem, and its' association with yield level and agronomic practices carried out in cinnamon fields. A detailed field survey was carried out in Galle, Matara, Ratnapura, Kalutara and Hambantota districts of Sri Lanka visiting 260 cinnamon lands during February to May 2013. Information was collected by interviewing the farmers, and making field observations. Significant negative correlations $(r=-0.668 ; p<0.05)$ were observed between the yield of cinnamon and incidence of wood borer (Ichneumoniptera cinnamomumi;) and rough bark disease (Phomopsis spp.; $r=-0.655$ ). Vertebrate pests such as barking deer and peacocks were making a significant damage on the new shoots that appear after harvesting. In addition, ten occasional pest and disease incidences and several minor pest and diseases were observed during the study period. There was a positive correlation between the severity of pest and disease incidence and the overuse of fertilizer and mammoty weeding. A negative correlation was observed between the pest and disease incidence and selective pruning, harvesting in short intervals (4 - 6 months), and slash weeding. Agronomic practices that had negative correlation with pest and disease incidence should be promoted through farmer awareness programmes. The results suggest upgrading the cinnamon crop management package to include these practices.
\end{abstract}

Keywords: Cinnamon, field survey, rough bark disease, vertebrate pests, wood borer

\section{Introduction}

Cinnamon (Cinnamomum zeylanicum Blume) is the most traditional export commodity of foreign trade in Sri Lanka from pre-colonial era to date. Cinnamon

\footnotetext{
${ }^{1}$ National Cinnamon Research and Training Center, Department of Export Agriculture, Sri Lanka

${ }^{2}$ Faculty of Agriculture, University of Peradeniya, Sri Lanka

${ }^{3}$ Department of Agriculture, Sri Lanka

* Corresponding Author: ggjaya2005@yahoo.co.in
} 
production is the primary source of income for around 60,000 farm families (around 300,000 people), cultivating 30,000 ha (Gunaratne, 2010). Foreign exchange earnings through cinnamon accounts for almost Sri Lanka Rs 17 billion, which is $49 \%$ of the earnings of Export Agricultural Crops in 2012 (Anonymous, 2013). The national average productivity of cinnamon ( $445 \mathrm{~kg} / \mathrm{ha}$ ) is far below the attainable yield (1000 kg/ha). Poor productivity is associated with aging of crop, poor crop maintenance, pest and disease incidence, etc. Major pest of cinnamon is the wood boring moth (Ichneumoniptera cinnamomumi). Identification (Dharmadasa and Jayasinghe, 2000; Jayasinghe et al., 2006), biology (Dharshanee et al., 2008) and management practices (Jayasinghe and Wickramasinghe, 2001; Jayasinghe et al., 2006; Jayasinghe, 2013) of the wood boring moth have been studied in detail. The rough bark disease (Phomopsis spp.) contributes mainly to the yield loss in cinnamon. Even though the disease has not been studied in detail, its' identification and control practices has been reported (Jayasinghe and Rathnasoma, 2013). Some minor pests such as upper leaf galls (Rajapakse and Ratnasekera, 1997) and lower leaf galls (Perera et al., 1985) have been identified. Although over 70 species of insect pests were reported in cinnamon in Sri Lanka and India (Anandaraj and Devasahayam, 2004), understanding on the nature of local pest complex and its association with yield was poor. Hence, this study was conducted with the objective of investigating the occurrence of pest complex in cinnamon ecosystem, its association with yield levels, its association with agronomic practices carried out in cinnamon field.

\section{Materials and Methods}

A detailed field survey was carried out during February to May 2013, in randomly selected 260 cinnamon lands in Galle (125), Matara (75), Ratnapura (20), Kulutara (20) and Hambantota (20) districts where cinnamon is mostly grown in Sri Lanka. Information was collected by using a pre-tested questionnaire survey to interview the growers, and by field observations. Special attention was given to the abundance of cinnamon pests and diseases using colour picture plates provided to enumerators. The survey was conducted by a group of extension workers who were well-trained on gathering information. As most of the collected data were nominal and ranked, the interpretations were made using bar charts, dot charts and radar charts. Only some relationships were subjected to regression and correlation analysis. All the analysis were done using Microsoft Excel computer software programme.

\section{Results and Discussion}

Two major pests namely, wood boring moth (Ichneumoniptera cinnamomumi) and rough bark disease (Phomopsis spp) were found to be widespread in the 
cinnamon fields. Abundance and severity of wood boring moth were 54.5 and $7.7 \%$ while those of rough bark disease were 37.5 and $27.7 \%$, respectively.

Significant negative correlations $(p<0.05)$ were observed between the yield of cinnamon and wood borer incidence $(r=-0.668)$ and rough bark disease incidence $(r=-0.655)$. The vertebrate pests such as barking deer, mouse, hair, squirrel and peacock were making a considerable damage on newly emerging shoots after harvest causing negative impact on cinnamon yield. Their damage abundance and severity were $50.0 \%$ and $12.4 \%$, respectively. In addition, ten occasional pests and disease incidences were identified i.e. thrips (not taxonomically described), root grubs (not taxonomically described), lower leaf gall (Eriophyes boisi), upper leaf gall (Trioza cinnamomi), leaf miner (Acrocercops spp.), wood boring weevil (Alcipes clauses), leaf blight (Colletotrichum gloeosporiodes), white root disease (Rigidoporus microporus), brown root rot (Phellinus noxius), and stem canker. Further, several minor pest and disease incidences namely, Sorolopha sp., Chilasaclitie (cinnamon butterfly), Attacus atlas, Xylebores arquatus, Phyllodesma spp. (lappet moth), Stenella sp. (black sooty mold), Cephaleuros virescens (algal leaf spot) and Exobasidium cinnamomi (fruit swollen disease) were identified.

The average cinnamon yield in the surveyed area was about $500 \mathrm{~kg} / \mathrm{ha}$, but it could be roughly categorized into four productivity levels (Figure 1) such as poor $(<300 \mathrm{~kg} / \mathrm{h})$, average $(<600 \mathrm{~kg} / \mathrm{h})$, economic ( $<900 \mathrm{~kg} / \mathrm{ha})$ and excellent $(900 \mathrm{~kg} / \mathrm{h}<)$. This clearly showed that the majority of farmers were far below the optimum productivity levels. These productivity levels were mainly reflected by intensity of application of good cultural practices and pests and diseases incidences, irrespectively, gaps created in cinnamon field due to ageing of the crop. Most of the cinnamon farmers were part time farmers (54\%), which is common for all districts. Less attention was given to the cinnamon fields and they mostly were avoided the good agricultural practices such as earthing up (heaping of soil into the base of bush), selective pruning, proper slash weeding and application of recommended fertilizer doze coupled with timely incorporation of organic manure. Majority of the cinnamon land (71\%) surveyed received urea-based fertilizer and mammoty weeding had been practiced. Both of these practices had positive correlation with wood boring moth damage and other pests and diseases as well. A recent study revealed that heaping of soil into the jutted out root ball due to mammoty weeding, had recovered the wood boring moth damage up to $90 \%$ (Jayasinghe and Wickramasinghe, 2001).

Selective pruning three months after harvesting, continuous harvesting (six month cycle), slash weeding at the occurrence of young shoots, soil conservation and mulching had negative correlation $(r=-0.72)$ with major pest damages (Figure 2). These practices appeared to be sufficient to keep the pest and disease incidences of cinnamon at a tolerable level. Even though majority of the farmers $(87 \%)$ were in positive mind on cinnamon cultivation, lack of 
knowledge to identify the pests and diseases at initial stages (16\%) was a major drawback in managing their incidences under cinnamon cultivation.

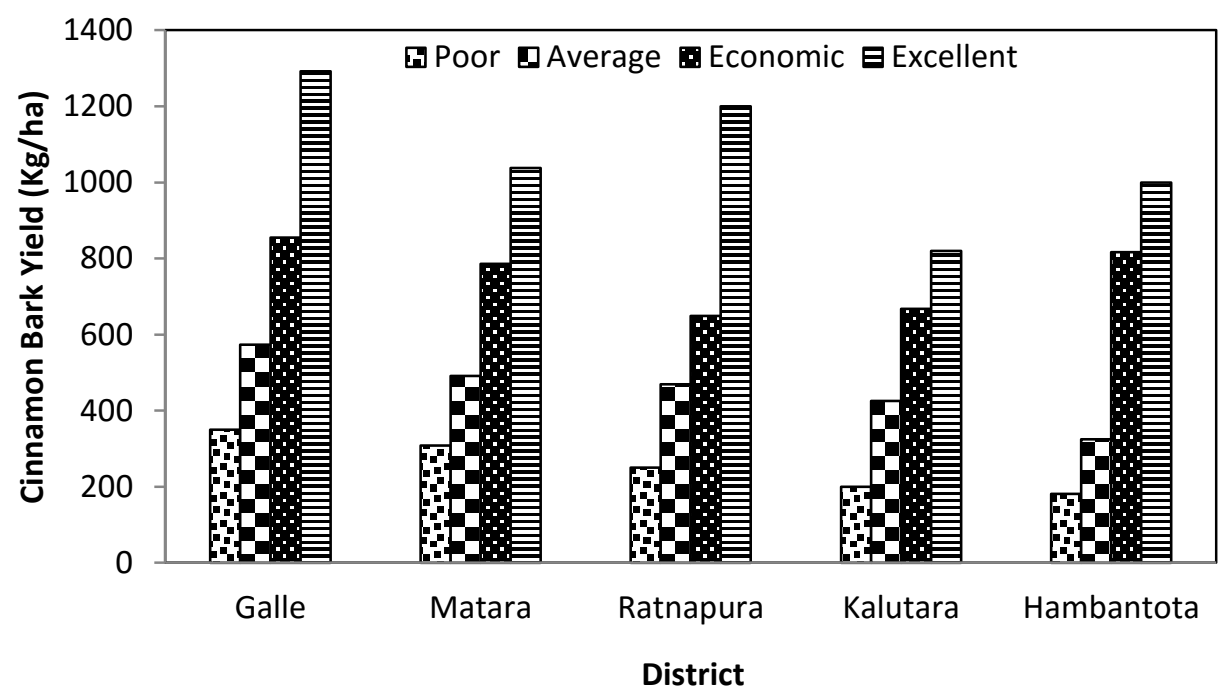

Figure 1. Different productivity levels of cinnamon lands in major cinnamon growing districts.

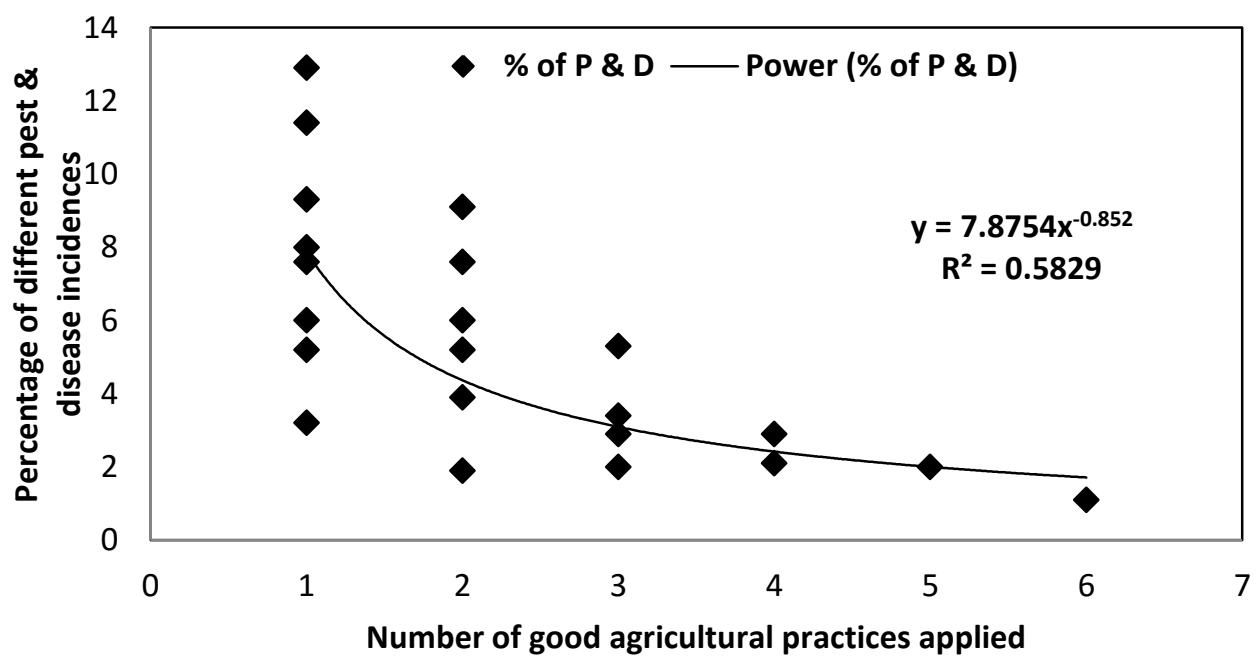

Figure 2. Relationship between the number of good management practices and incidents of pest and diseases (P \& D) during the study period (Note: incidences less $1 \%$ were omitted).

\section{Conclusions}

Cinnamon was the major income source for majority of the cinnamon farmers in every district surveyed. Use of preferable cultural practices such as earthing up, selective pruning, proper slash weeding and application of recommended 
fertilizer doze with organic manure seems to have influenced the reduction in the pest and disease incidences and thus, increasing the productivity of cinnamon lands. However, further investigations on the relationship between cultural practices and productivity of cinnamon lands with well-planned field experiments are necessary prior to drawing conclusions.

\section{Acknowledgement}

Authors acknowledge the Sri Lanka Council for Agriculture Research Policy (CARP) for providing grant approval for this project and the extension officers of the Department of Export Agriculture in the relevant districts for their active contribution at the survey as enumerators.

\section{References}

Anandaraj, M. and Devasahayam, S. (2004): Pest and diseases of cinnamon and cassia, In: The genus Cinnamomum: Medicinal and Aromatic plant - Industrial Profiles (Eds. P.N. Ravindran, K. Nirmal Babu and M. Shylaja). pp 239 -259. CRC Press, New York.

Anonymous (2013): Market information on Export Agriculture Crop 2013. Department of Export Agriculture, Ministry of Minor Export Crop Promotion. 35 p.

Dharshanee, H.L.C., Dharmadasa, M., Nugaliyadda, L. and Wijesinghe, K.G.G. (2008): Development of a pheromone based management method for cinnamon wood boring moth (Ichneumoniptera cinnamomumi) (Lepidoptera: Sesiidae). Proceedings of the National Symposium (Abstracts), Faculty of Agriculture, University of Ruhuna, Sri Lanka, pp31.

Dharmadasa, M. and Jayasinghe, G.G. (2000): A clearwing moth (Synanthedon spp.), a new pest damage in cinnamon cultivations and its damage severity in Sri Lanka. Proceedings - Part 1 - Abstracts, SLAAS, Colombo, $91 \mathrm{p}$.

Gunarathne W.D.L. (2010): Market information of export agriculture crops. pp 1-2.

Jayasinghe, G.G. (2013). Integrated management of cinnamon clearwing moth (Ichneumoniptera cinnamomumi Tosevski) using eathing-up, insecticides and sex pheromones. Annual Symposium of Minor Export Crops (Ed. B. Marambe). Vol. 2, pp 73-79, 12 -13 Sep. Peradeniya, Sri Lanka.

Jayasinghe, G.G. and Rathnasoma, H.A. (2013): Efficacy of Fungicides for Managing Rough Bark Disease (Phomopsis sp.) in Cinnamon (Cinnamomum zeylanicum Blume), Proceedings - Part 1 - Abstracts, SLAAS, Colombo, Sri Lanka. $2^{\text {nd }}-$ $6^{\text {th }}$ December.

Jayasinghe, G.G., Gunaratne, W.D.L., Dharshanee, H.L.C., Griepink, F.C., Louwaars, N.P. and Stol, W. (2006): Environmentally sound insect control in cinnamon: A feasibility study on the use of insect pheromones to replace large-scale use of insecticides, Report 119, Plant Research International B.V., Wageningen, The Netherlands.

Jayasinghe, G.G. and Wickramasinghe, P.J. (2001): Control measures of wood boring moth (Synanthidon sp.) in cinnamon (Cinnamomum verum Presl.). Sri Lanka 
Jayasinghe et al.

Association for the Advancement of Science, $57^{\text {th }}$ Annual session, Proceedings Part 1 - Abstracts, pp 59.

Perera, H.A.S., Sritharan, R. and Perera, K.P. (1985): Some studies of cinnamon galls in Sri Lanka. Sri Lankan J. Agric. Sci., 22 (1): $23-27$.

Rajapakse, R.H.S. and Ratnasekera, D. (1997): Studies on the distribution and control of leaf galls in cinnamon caused by Triozacinnamomi Boselli in Sri Lanka. Indian J. Tropical Agric., 15(1-4): 53-56. 